\title{
ENZYMATIC ACTIVITY OF ALKALINE PROTEASE FROM Bacillus cereus TD5B AND ITS APPLICATION AS SHEEP SKIN DEHAIRING AGENT
}

\section{Nanung Agus FITRIYANTO ${ }^{1 *}$, MUSTHOFIYAH ${ }^{1}$, MUHLISIN ${ }^{2}$, Ambar PERTIWININGRUM ${ }^{1}$, Novita KURNIAWATI ${ }^{1}$, Ragil Adi PRASETYO ${ }^{1}$, Aldyon Restu AZKARAHMAN ${ }^{1}$, Yuny ERWANTO ${ }^{1}$}

1Department of Animal Products Technology, Faculty of Animal Science, Universitas Gadjah Mada, Indonesia; nanungagusfitriyanto@ugm.ac.id (N.A.F); musthofiyah@mail.ugm.ac.id (M); artiwi@mail.ugm.ac.id (A.P.); novita@ugm.ac.id (N.K.); ragiladip27@mail.ugm.ac.id (R.A.P); aldyon.restu.a@mail.ugm.ac.id (A.R.A); yunyer@ugm.ac.id

2Department of Animal Nutrition and Feed Science, Faculty of Animal Science, Universitas Gadjah Mada, Indonesia; muhlisin.fapet@ugm.ac.id

ENZYMATIC ACTIVITY OF ALKALINE PROTEASE FROM Bacillus cereus TD5B AND ITS APPLICATION AS SHEEP SKIN DEHAIRING AGENT ABSTRACT. This study aims to determine the enzymatic activity of extracellular alkaline protease from Bacillus cereus TD5B and its potential application as a sheep skin dehairing agent. The $B$. cereus TD5B was screened for extracellular alkaline protease production on skim milk agar media, while its alkaline protease activity and the application were measured at $1 \%, 1.5 \%$, and $2 \%$. The application of alkaline protease from B. cereus TD5B as a sheep skin dehairing agent was observed through histological examination and physical properties measurement after chrome-tanning with lime and $\mathrm{Na}_{2} \mathrm{~S}$ as control. The study was conducted in a completely randomized design, and the quantitative data were analyzed using Duncan's Multiple Range Test. The results showed that a clear zone was seen surrounding $B$. cereus, indicating the bacteria's proteolytic activity. The protease activity measurement showed that $2 \%$ of alkaline protease had the highest enzymatic activity at $144.75 \mathrm{U} / \mathrm{mL} / \mathrm{min}$. The highest tensile strength of sheep leather was obtained after dehairing at $1 \%$ alkaline protease concentration $\left(350.26 \mathrm{~kg} / \mathrm{cm}^{2}\right)$, even though the highest elongation was obtained at $2 \%(34.92 \%)$. In contrast, different concentrations showed similar shrinkage temperatures at $90^{\circ} \mathrm{C}$. This study concludes that the optimum alkaline protease concentration from Bacillus cereus TD5B as a sheep dehairing agent was $2 \%$.

KEYWORDS: Bacillus cereus TD5B, dehairing, alkaline protease, sheep skin

\section{ACTIVITATEA ENZIMATICĂ A PROTEAZEI ALCALINE DIN Bacillus cereus TD5B ȘI APLICAREA ACESTEIA PE PIELEA DE OAIE CA AGENT DE} ÎNDEPĂRTARE A PĂRULUI

REZUMAT. Acest studiu are ca scop determinarea activității enzimatice a proteazei alcaline extracelulare din Bacillus cereus TD5B și a potențialei sale aplicații ca agent de îndepărtare a părului de pe pielea de oaie. S-a selectat $B$. cereus TD5B pentru producția de protează alcalină extracelulară pe mediu de agar din lapte degresat, măsurându-se activitatea proteazei alcaline și aplicarea acesteia în proporție de 1\%, 1,5\% și 2\%. Aplicarea proteazei alcaline din B. cereus TD5B ca agent de îndepărtare a părului de pe pielea de oaie a fost observată prin examinarea histologică și s-au determinat proprietățile fizice după tăbăcirea în crom cu var și $\mathrm{Na}_{2} \mathrm{~S}$ ca martor. Studiul a fost realizat într-un design complet randomizat, iar datele cantitative au fost analizate folosind testul Duncan cu rază multiplă. Rezultatele au arătat că s-a văzut o zonă liberă în jurul B. cereus, indicând activitatea proteolitică a bacteriei. Măsurarea activității proteazei a arătat că proporția de $2 \%$ din proteaza alcalină a avut cea mai mare activitate enzimatică la $144,75 \mathrm{U} / \mathrm{ml}$ min. Cea mai mare rezistență la tracțiune a pielii de oaie a fost obținută după îndepărtarea părului folosind protează alcalină la o concentrație de $1 \%\left(350,26 \mathrm{~kg} / \mathrm{cm}^{2}\right)$, chiar dacă alungirea cea mai mare a fost obținută la concentrația de $2 \%(34,92 \%)$. În schimb, concentrații diferite au arătat o temperatură de contracție similară la $90^{\circ} \mathrm{C}$. Acest studiu concluzionează că concentrația optimă de protează alcalină din B. cereus TD5B ca agent de îndepărtare a părului de pe pielea de oaie a fost de $2 \%$.

CUVINTE CHEIE: Bacillus cereus TD5B, agent de îndepărtare a părului, protează alcalină, piele de oaie

\section{L’ACTIVITÉ ENZYMATIQUE DE LA PROTÉASE ALCALINE DE Bacillus cereus TD5B ET SON APPLICATION COMME AGENT D'ÉLIMINATION} DES CHEVEUX POUR LA PEAU DE MOUTON

RÉSUMÉ. Cette étude vise à déterminer l'activité enzymatique de la protéase alcaline extracellulaire de Bacillus cereus TD5B et son application potentielle comme agent d'élimination des cheveux pour la peau de mouton. Le $B$. cereus TD5B a été sélectionné pour la production de protéase alcaline extracellulaire sur milieu gélose au lait écrémé, tandis que l'activité de la protéase alcaline et l'application ont été mesurées à $1 \%, 1,5 \%$ et $2 \%$. L'application de protéase alcaline de $B$. cereus TD5B comme agent d'élimination des cheveux de la peau de mouton a été observée par examen histologique et les propriétés physiques ont été mesurés après tannage au chrome avec de la chaux et du $\mathrm{Na}_{2} \mathrm{~S}$ comme témoin. L'étude a été menée dans un plan complètement aléatoire et les données quantitatives ont été analysées à l'aide du test à plages multiples de Duncan. Les résultats ont montré qu'une zone claire était observée autour de $B$. cereus, indiquant l'activité protéolytique de la bactérie. La mesure de l'activité protéase a montré que $2 \%$ de la protéase alcaline avait l'activité enzymatique la plus élevée à $144,75 \mathrm{U} / \mathrm{mL} / \mathrm{min}$. La résistance à la traction la plus élevée du cuir de mouton a été obtenue après épilation à une concentration de protéase alcaline de $1 \%\left(350,26 \mathrm{~kg} / \mathrm{cm}^{2}\right)$, même si l'allongement le plus élevé a été obtenu à $2 \%(34,92 \%)$. En revanche,

\footnotetext{
* Correspondence to: Nanung Agus FITRIYANTO, Department of Animal Products Technology, Faculty of Animal Science, Universitas Gadjah
} Mada, Indonesia; nanungagusfitriyanto@ugm.ac.id 
différentes concentrations ont montré une température de retrait similaire à $90^{\circ} \mathrm{C}$. Cette étude conclut que la concentration optimale de protéase alcaline de $B$. cereus TD5B en tant qu'agent d'élimination des cheveux des moutons était de $2 \%$.

MOTS CLÉS : Bacillus cereus TD5B, agent d'élimination des cheveux, protéase alcaline, peau de mouton

\section{INTRODUCTION}

The tannery industry is an animal byproduct processing industry that produces flexible and durable leather from livestock skins [1]. Due to the uniqueness and beauty of the leather, the natural product is favoured by consumers and preferred over synthetic materials [2]. However, the leather processing industries face challenges due to the generated pollution, which harms the environment. The commercial leather-making process involves sequential stages: pretanning, tanning, post-tanning, and finishing, which uses and expels chemicals. Among the pre-tanning stage operations, dehairing is an important step to remove hair, epidermis, non-collagenous proteins, and other cementing substances from the skin [3]. The conventional dehairing process uses saturated lime and sodium sulfide at high concentrations and contributes to $50-60 \%$ of the total dissolved solids and chemical and biochemical oxygen demand in the effluent [4].

The negative impacts of the leather processing waste on the environment and increased consumers' awareness encourage the industry to adopt cleaner processing methods. One of the more eco-friendly and sustainable approaches in leather processing is the use of enzymatic dehairing. Enzymebased dehairing processes utilize proteolytic enzyme, or widely known as protease, which leads to a reduction of effluent load and toxicity. Also, improvement in leather quality is a viable alternative to the conventional chemical-based process [5].

Protease enzyme has represented about $60-65 \%$ of the total industrial enzyme market and could be obtained from various resources, such as animals, plants, and microorganisms [6]. Protease catalyzes the protein hydrolysis to polypeptides and oligopeptides to amino acids and is classified depending on the $\mathrm{pH}$ and their active site structure. The selection of enzyme sources plays a key role in obtaining desirable enzymes. Nowadays, Bacillus spp. strains are favored as a protease source due to their wide temperature and $\mathrm{pH}$ tolerance. Proteases from Bacillus spp. are widely used in food, pharmaceutical, detergent, leather industries, waste treatment, synthesis of oligopeptides $[7,8]$, and potential application for dehairing without affecting the quality of produced leather [9].

Bacillus cereus TD5B is proteaseproducing bacteria isolated from a farm area in Yogyakarta [10] and has shown increased enzymatic activity through ammonium sulfate purification [11]. Furthermore, B. cereus TD5B has also been shown to hydrolyze duck meat for angiotensin converting enzyme inhibitor production [12] and producing keratinase for poultry feather waste treatment [13]. In the present study, the enzymatic activity of extracellular alkaline protease from $B$. cereus TD5B and its application as sheep skin dehairing agents were observed to determine its potential to be utilized in the leather processing industry as an enzymatic dehairing agent.

\section{EXPERIMENTAL}

\section{Materials and Methods}

\section{Bacterial Isolation, Medium, and Culture}

The strain is obtained initially from a soil sample collected at ammonia highemitted chicken hen production area in tropical country Indonesia. Soil samples (1.0 g) collected from various spots in a most odorous region were then suspended in $10 \mathrm{~mL}$ pure, sterile water and diluted appropriately. A portion of the cell suspension was spread on a 1/100 nutrient agar plate with a high concentration of $\left(\mathrm{NH}_{4}\right)_{2} \mathrm{SO}_{4}$ as an organic ammonium stressor $\left(500 \mathrm{mg} / \mathrm{L} \quad\left(\mathrm{NH}_{4}\right)_{2} \mathrm{SO}_{4}\right)$. Colonies appearing on the plate were then picked and purified. Each purified colony was 
inoculated on an agar plate with and without ammonium stressor. Microorganisms displaying proper growth on the agar with $\left(\mathrm{NH}_{4}\right)_{2} \mathrm{SO}_{4}$ were selected as ammoniumresponsive microorganisms. Isolates were then purified by plating on $1 / 100$ nutrient broth $10.01 \%$ meat extract, $0.01 \%$ polypeptone, and $0.005 \% \mathrm{NaCl}, \mathrm{pH}$-value adjusted 7.2) supplemented with $500 \mathrm{mg} / \mathrm{L}$ $\left(\mathrm{NH}_{4}\right)_{2} \mathrm{SO}_{4}$ and continued by incubation at $30^{\circ} \mathrm{sC}$ for $48 \mathrm{~h}$ in aerobic condition.

\section{Bacterial Screening}

Colony from the selected strain was then identified based on the potency as proteolytic bacteria. The strains were screened for extracellular protease production using skim milk agar media containing $(\mathrm{w} / \mathrm{v})$ : $0.5 \%$ peptone; $0.25 \% \mathrm{NaCl} ; 2 \%$ agar powder; $0.5 \%$ meat extract; and $1.5 \%$ skim milk, diluted on $100 \mathrm{~mL}$ distilled water. Positive results are shown in a clear zone of hydrolysis around the colonies [15]. Microorganisms showing a clear zone of skim hydrolyzed around their colonies were picked up for further identification, based on the morphological and molecular characteristics. Molecular characterization was further done by the 16S rRNA gene sequencing method.

\section{Observation of the Strain Morphology}

The morphological characteristic was observed by scanning electron microscopy (SEM) [14]. The SEM sample was prepared by transferring the biomass of selected microbial strain harvested after $48 \mathrm{~h}$ incubation to a clean Eppendorf tube containing approximately $1.5 \mathrm{~mL}$ of $3.5 \%$ glutaraldehyde solution. Then, the culture was incubated for $4 \mathrm{~h}$ at room temperature, followed by a wash with phosphate buffer (100 mM, pH 7.2). The culture is dehydrated through a series of $50 \%$ to $100 \%$ ethanol solutions. The filter was mounted on the stub, coated with gold, and examined under a scanning electron microscope (JEOL JSM-6510LA, Hitachi Limited, Japan).
Identification of 165 rRNA Gene Sequencing and Phylogenetic Analysis

The molecular characteristics were done by the $16 \mathrm{~S}$ rRNA gene sequencing method. The $16 \mathrm{~S}$ rRNA was amplified by PCR using universal primers. The purified PCR product was then sequenced using BigDye Terminator v3.1 Cycle Sequencing Kit from Applied Biosystems, USA with the ABI Prism 310 Genetic Analyzer (Applied Biosystems) and analyzed using the BLAST version 2.2.18 (BLASTN) to compare with the public database of DDBJ (http://blast.ddbj.nig.ac.jp). Molecular taxonomy, sequencing, and phylogenetic analysis of DNA were isolated from the biomass selected bacteria harvested at $48 \mathrm{~h}$. Genomic DNA of the bacterium was extracted by standard methods. The PCR was carried out to amplify about 1500 bp fragment of the $16 \mathrm{~S}$ rRNA gene using primers designed based on the conserved region of the $16 \mathrm{~S}$ rRNA gene for bacteria. A combination of forward primers $16 \mathrm{~S}$ forward (5AGAGTTTGATCCTGGCTCAG-3) and 16S reverse (5-GGYTACCTTGTTACGACTT-3) was applied to amplify the $16 \mathrm{~S}$ rRNA sequence of bacteria. The PCR was performed using PCR thermal cycler (Applied Biosystem, USA). The PCR conditions and the methodology for sequencing were followed as per procedure [10]. The purified DNA was sequenced using a DNA analyzer (Applied Biosystems), and the sequences were aligned and assembled using the sequencher 4.7 program (GENE CODES). The 16S rRNA partial gene sequence similarities were studied using the National Center for Biotechnology Information-BLAST search. The high similarity sequences deposited in the DNA database and isolates' identities were calculated by the highest score (> 98\%). The phylogenetic tree was constructed with a neighbor-joining algorithm method performed using Clustal $\mathrm{W}$ and viewed using FigTree v1.4.0.

\section{Bacterial Growth and Cultivation}

The selected isolate was first cultivated into pre-culture by incubating the isolate on $\mathrm{pH} 7.0$ stock solution $(1 \mathrm{~g}$ meat extract, $1 \mathrm{~g}$ biological peptone, $0.5 \mathrm{~g} \mathrm{NaCl}$, and $70 \mathrm{ml}$ distilled water) for $24-\mathrm{h} 27^{\circ} \mathrm{C}$ with continuous 
shaking (120 rpm). The culture media for Bacillus cereus TD5B protease production was composed of $1 \mathrm{~g}$ meat extract, $1 \mathrm{~g}$ peptone, $0.5 \mathrm{~mL} \mathrm{NaCl}, 2 \mathrm{~g}$ skim milk agar, and distilled water reached $100 \mathrm{~mL}$. The culture solution was set at $\mathrm{pH} 7.2$ and inoculated with $1 \mathrm{~mL}$ pre-culture and incubated on a rotary shaker (120 rpm) for $24-\mathrm{h}$ at $27^{\circ} \mathrm{C}$. The culture was centrifuged at $6000 \mathrm{rpm}\left(4^{\circ} \mathrm{C}\right)$ for 10 minutes, and the supernatant was used for proteolytic activity assay.

\section{Enzyme Assay}

The supernatant $(3 \mathrm{ml})$ was mixed with $1 \mathrm{ml}$ of casein dissolved in $0.2 \mathrm{M}$ phosphate buffer ( $\mathrm{pH} \mathrm{8.0)}$ and was incubated at $37^{\circ} \mathrm{C}$ for $30 \mathrm{~min}$. The reaction was stopped by the addition of $5 \mathrm{ml}$ of $5 \%$ trichloroacetic acid. The blank was also prepared by adding TCA before the enzyme addition and incubated at the same condition. The sample test and the blank test solutions were then filtered through a Whatman No. 1 filter paper. For $1.5 \mathrm{ml}$ of the filtrate, $5 \mathrm{ml}$ of $0.4 \mathrm{M} \mathrm{Na}_{2} \mathrm{CO}_{3}$ and $1 \mathrm{ml}$ of 0.5 $\mathrm{N}$ Folin Ciocalteu reagent were added and mixed thoroughly. The absorbance was measured at $578 \mathrm{~nm}$ by the UV Visible spectrophotometer. One unit of protease activity is defined as the amount of enzyme which liberated $1 \mu \mathrm{mol}$ of tyrosine per min at $37^{\circ} \mathrm{C}$.

\section{Sheep Skin Dehairing Application}

Wet salted sheep skins were used for the dehairing application. Before dehairing, the sheep skins were cut into $10 \times 10 \mathrm{~cm}$, washed, and soaked by water and $0.5 \%(\mathrm{w} / \mathrm{v})$ detergent for $30 \mathrm{~min}$ in a mini cylindrical rotating drum. Alkaline protease enzyme was then added at $1 \%, 1.5 \%$, and $2 \%(\mathrm{w} / \mathrm{v})$ and left for 18-h at room temperature and then dehaired by rubbing. Depilated sheep skins were cut at $0.75 \times 0.5 \mathrm{~cm}$ for histological examination, while the rest were processed into leather for physical properties measurement.

\section{Leather Processing}

The dehaired sheep skin was processed into the leather by chrome tanning (8\%) for 60 to $120 \mathrm{~min}$, followed by bating for seven times with $1 \%(\mathrm{w} / \mathrm{v})$ formic acid and $1.75 \%(\mathrm{w} / \mathrm{v})$ sodium bicarbonate for 15 minutes each, retanning with $150 \%(\mathrm{w} / \mathrm{v})$ water, $0.5 \%$ formic acid, and $0.3 \%$ wetting agent for 30 to $60 \mathrm{~min}$, and washing with $200 \%(\mathrm{w} / \mathrm{v})$ water and $0.5 \%$ $(\mathrm{w} / \mathrm{v})$ formic acid for $20 \mathrm{~min}$.

\section{Histological Examination}

Dehaired sheep skin pelts were cut into $0.75 \times 0.5 \mathrm{~cm}$, washed, and fixed in $10 \%$ formic acid $(\mathrm{w} / \mathrm{v})$ to be used as a sample. To analyze the histology feature, samples were then embedded in paraffin block with haematoxylin and eosin (H\&E) staining [17].

\section{Leather Physical Properties Measurement}

The physical measurement of this study has included tensile strength, elongation, and shrinkage temperature. The tensile strength and elongation of sheep leather were measured as per standard International Union for Physical testing for Leather IUP methods EN ISO 3376 (IULTCS/IUP 6, 2011) [18] and EN ISO 17236 (IULTCS/IUP 43, 2016) [19]. The tanned leather's shrinkage temperature was analyzed following ISO 3380:2015 (IULTCS/IUP 16) [20]. The leather samples were all completely vertically immersed in glycerine at $20 \pm 2^{\circ} \mathrm{C}$, and the heating rate was $2 \pm 0.2^{\circ} \mathrm{C} \cdot \mathrm{min}^{1}$.

\section{Statistical Analysis}

The study was conducted in a completely randomized design. All the experiments were carried out in triplicates, and the mean \pm standard deviation has been plotted. The bacterial screening and histological examination were analyzed descriptively. Other quantitative data were analyzed statistically using Duncan's Multiple Range Test (DMRT) with the significant value set at $P \leq 0.05$.

\section{RESULTS AND DISCUSSIONS}

\section{Screening Bacillus cereus TD5B}

B. cereus TD5B was isolated from soil at odorous layer hen farm in Yogyakarta, Indonesia [10]. The strain was initially plated on Skim Milk Agar (SMA) at pH 7.2. Growing 
on SMA medium for $24-\mathrm{h}$ at $30^{\circ} \mathrm{C}$ has shown a clear zone formation surrounding the colonies (Figure 1). The formation of a clear zone indicates the strain's proteolytic activity, while its activity on $\mathrm{pH} 7.2$ indicates alkaline protease production by the bacteria.

The formation of a clear zone in SMA medium was due to the skim milk protein hydrolysis, which has been catalyzed by the bacteria's extracellular protease. Thus, a clear zone would be formed surrounding the bacteria colony. The clear zone formation on SMA medium has been a widely utilized method to determine bacterial screening for proteolytic activity, especially for Bacillus strain [9]. Bacillus strains have been known to possess the alkaline proteolytic activity and are described in many papers for their applications, mainly directed to detergents [22] and the tannery industry [23]. The study by Kasana and Yadaf [24] also used this method to screen alkaline protease production of psychotropic Exiguobacterium sp. SPKB5, while [25] used the clear zone formation method to determine de-hairing protease production on $B$. cereus strain AT from cow dung. The clear zone formation in the SMA medium in this study confirmed that $B$. cereus TD5B could produce an alkaline protease enzyme.

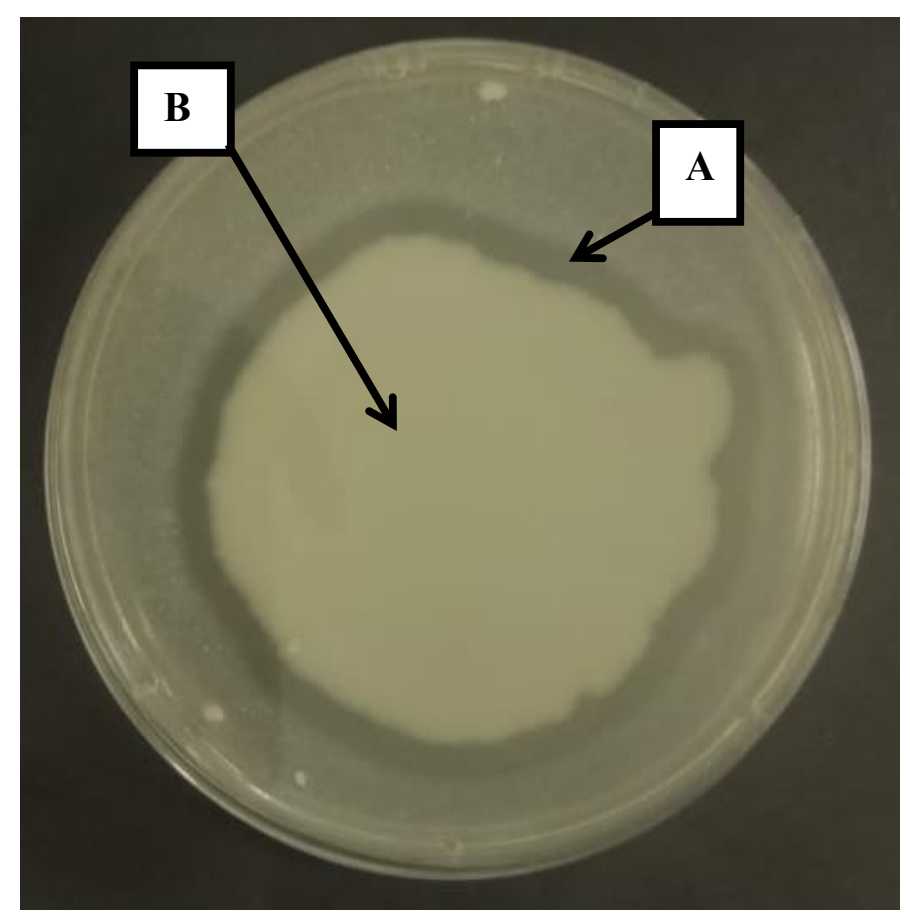

Figure 1. Proteolytic activity of $B$. cereus TD5B on SMA medium. $A=$ clear zone; $B=$ bacteria colony

\section{Identification and Characterization of Bacillus cereus TD5B}

Scanning Electron Microscope (SEM) was used to identify the strain's morphological properties (Figure 2). The strain was found to be aerobic, motile, sporeforming, and rod-shaped. The 16S rRNA partial gene sequence of strain TD5B showed sequence similarity with the published $16 \mathrm{~S}$ rRNA gene sequences of $B$. cereus. The phylogenetic tree (Figure 3) was constructed by the neighbor-joining method using Clustal W software [21]. 


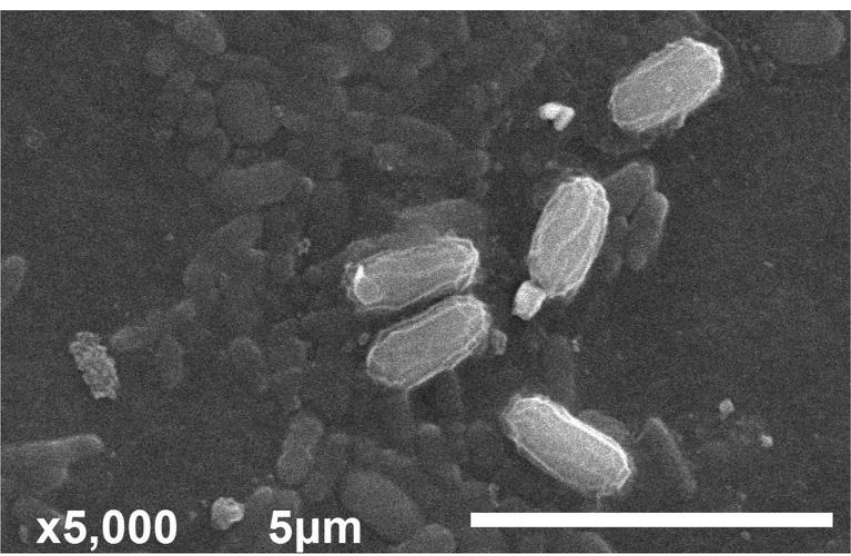

Figure 2. SEM image of $B$. cereus TD5B

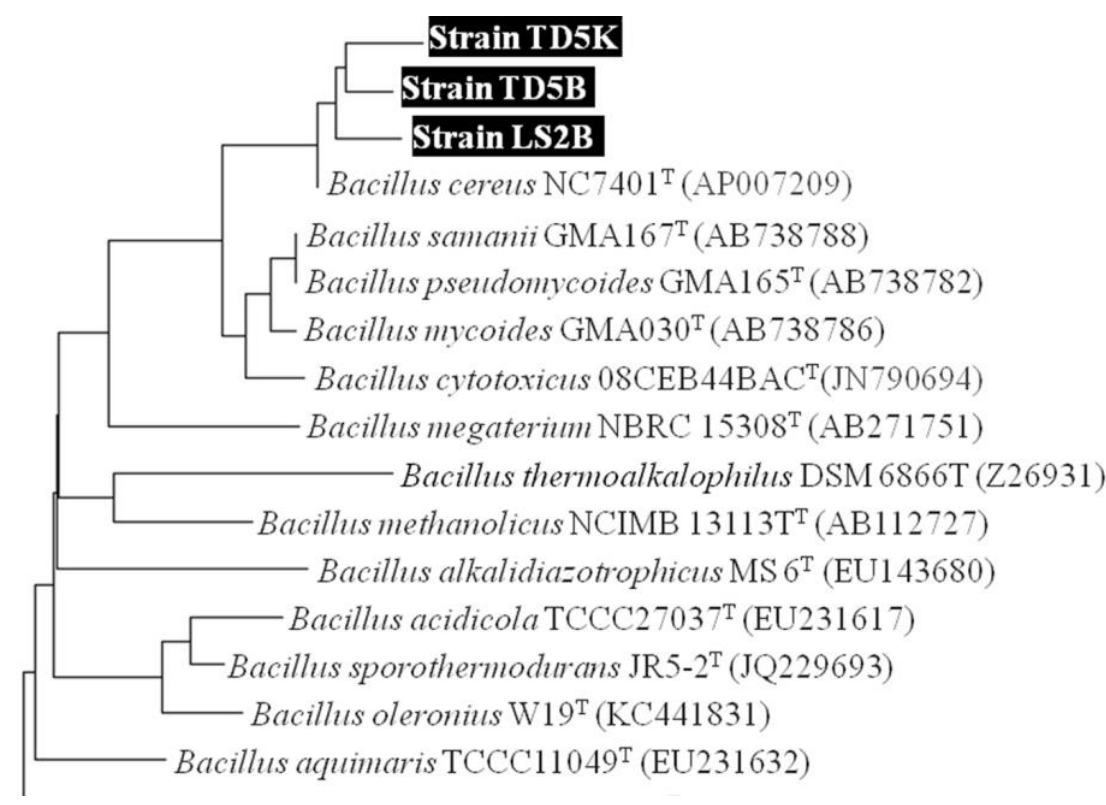

Figure 3. The relationships between Bacillus cereus TD5B and members of Bacillus strains on rooted neighbor-joining tree based on $16 \mathrm{~S}$ rRNA sequences

\section{Enzymatic Activity}

The extracellular alkaline protease of $B$. cereus TD5B was extracted and measured for its proteolytic activity under different concentration levels $(1 \%, 1.5 \%$, and $2 \%)$. The different concentration levels measurement was aimed to understand its activity before applying it for sheep skin dehairing. The result of alkaline protease activity of $B$. cereus TD5B measurement at different concentration levels in this study is presented in Figure 4. 


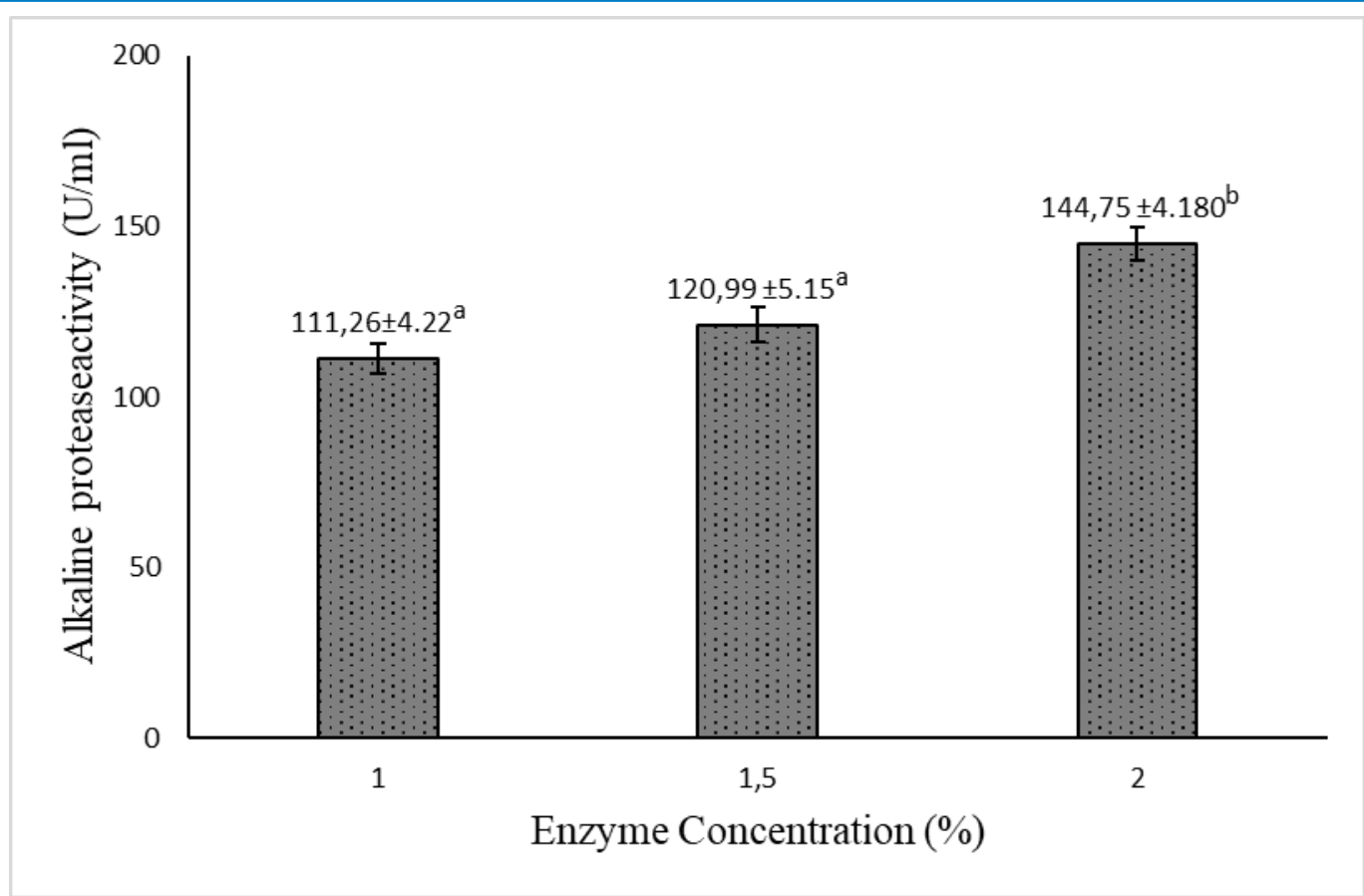

Figure 4. Alkaline protease activity of B. cereus TD5B

The results showed that alkaline protease of $B$. cereus TD5B concentration positively correlates with enzymatic activity; higher alkaline protease concentration application has shown higher enzymatic activity. In this study, we found that $1 \%$ alkaline protease of $B$. cereus TD5B had enzymatic activity at $111 \pm 4.22 \mathrm{U} / \mathrm{ml}$, while at $1.5 \%$ and $2 \%$ concentration the enzymatic activity was at $120.99 \pm 5.15 \mathrm{U} / \mathrm{ml}$ and $144.75 \pm 4.80 \mathrm{U} / \mathrm{ml}$, respectively. The enzymatic activity of alkaline protease from $B$. cereus TD5B in this study was higher compared to crude alkaline protease from Bacillus sp. SB12, which was at $114 \mathrm{U} / \mathrm{mg}$ [9].

In this study, the alkaline protease from B. cereus TD5B was produced at $27^{\circ} \mathrm{C}$ and $\mathrm{pH}$ 7.2. At a similar temperature, another researcher [24] showed that the alkaline protease activity of Streptomyces sp. Al-Dhabi82 was at $48 \pm 2.8 \mathrm{U} / \mathrm{ml}$, significantly lower than B. cereus TD58 in all different concentration levels in this study. Research has shown that the microbial enzymatic activity is affected by various factors, such as temperature, $\mathrm{pH}$, fermentation period, carbon and nitrogen source, and used substrates [9, $25,26]$. Investigations on the effect of temperature revealed that $37^{\circ} \mathrm{C}$ was the optimum value for maximum protease production by Bacillus species [27].

Furthermore, research on Bacillus licheniformis RKK-04 [28] and Bacillus subtilis RTSBA6 [29] showed that both strains had a protease thermal stability range of $25^{\circ} \mathrm{C}$ to $50^{\circ} \mathrm{C}$. Aside from $\mathrm{pH}$ and temperature, the media's carbon and nitrogen sources also affect alkaline protease activity $[25,30]$. However, the study on different environmental conditions towards protease production of $B$. cereus TD5B has not been done in this study. Thus, an approach to further optimize the proteolytic activity of $B$. cereus is possible by modifying the environmental condition of the media.

\section{Enzymatic Sheep Skin Dehairing Application}

The histological examination of dehaired sheep skin was observed using a photomicrograph (Figure 5). 


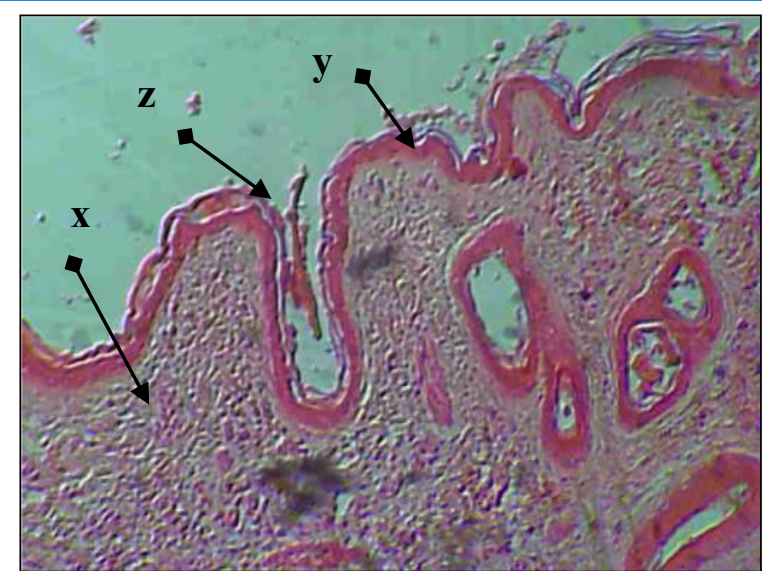

(A)

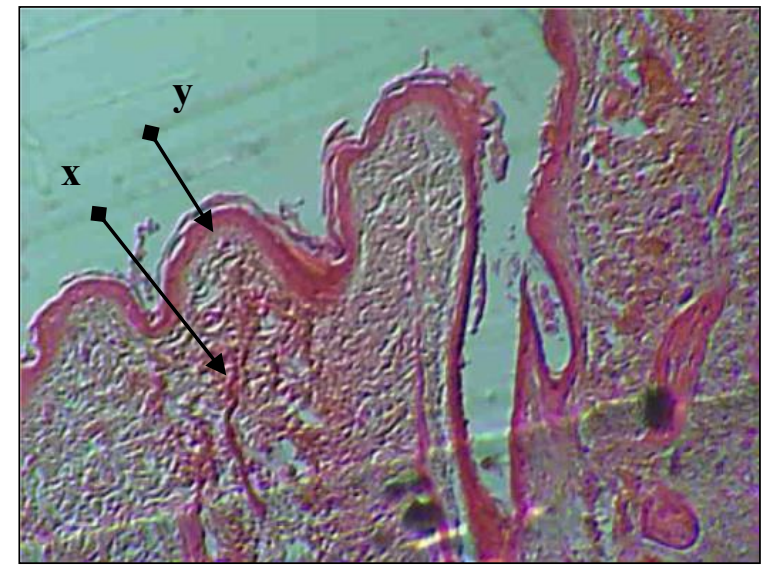

(C)

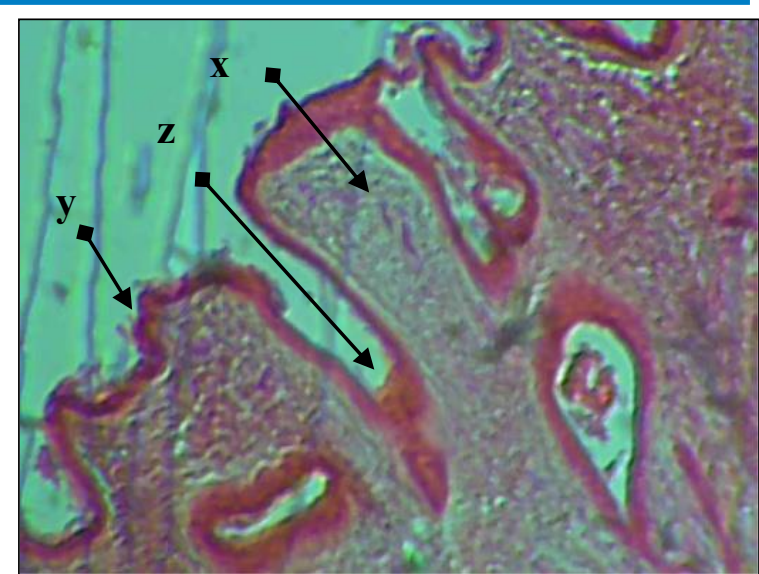

(B)

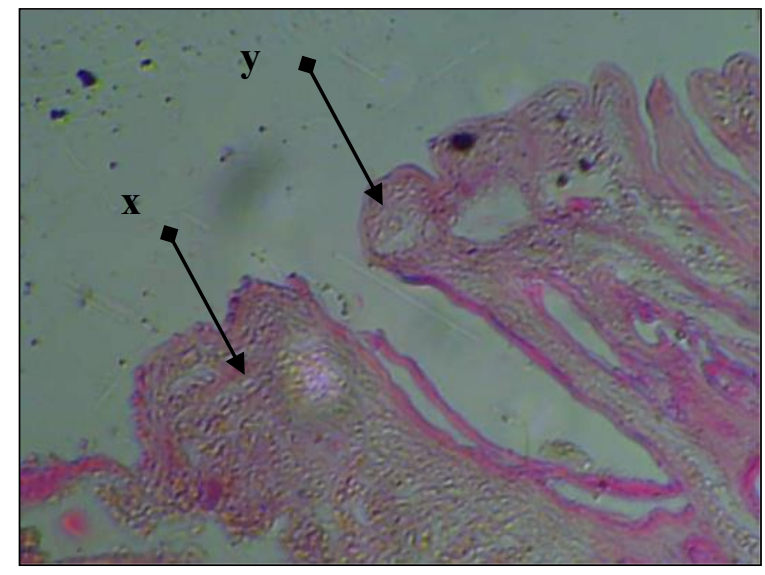

(D)

Figure 5. Histological examination of dehaired sheep skin. $A=1 \%$ alkaline protease; $B=1.5 \%$ alkaline protease; $\mathrm{C}=2 \%$ alkaline protease; $\mathrm{D}=$ lime and $\mathrm{Na}_{2} \mathrm{~S} ; \mathrm{x}=$ dermal papillae; $\mathrm{y}=$ reticular papillae; $\mathrm{z}=\mathrm{hair}$.

The dehairing process aims to remove the skin epidermis and hair by removing epidermal keratins without damaging the dermal collagen fibers. The result showed that protease $B$. cereus TD5B has a noncollagenolytic effect on the hide and a nonkeratinolytic effect on the hair. Other research [31] showed that dehairing proteases result in the degradation of the cells in the Malpighi's layer and the hair bulb's basal cells. In Figure 5 , it can be seen that alkaline protease of $B$. cereus TD5B at all concentration levels did less damage to the sheep skin than the usage of lime and $\mathrm{Na}_{2} \mathrm{~S}$. Other reports showed that proteolytic enzymes destroyed the soft keratin tissues during dehairing, which is sufficient to remove the hair without damaging the collagen dermal fibers [32]. It showed that the enzymatic dehairing of alkaline protease from $B$. cereus TD5B yields better sheep skin quality than lime and $\mathrm{Na}_{2} \mathrm{~S}$ to be further processed into leather. However, the histological examination showed that enzymatic dehairing of sheep skin at $1 \%$ and $1.5 \%$ concentration level in this study still left several hairs intact to the skin. In comparison, at $2 \%$ concentration levels, the sheep hair was fully dehaired from the skin.

\section{Leather Physical Properties}

The physical properties of enzymatic dehaired sheep skin by using alkaline protease from $B$. cereus TD5B at different concentration levels $(\mathrm{P} 1=1 \% ; \mathrm{P} 2=1.5 \%$; and $\mathrm{P} 3=2 \%$ ) was observed and compared to the conventional dehairing by using lime and $\mathrm{Na}_{2} \mathrm{~S}$ (PO) to understand the potential application of $B$. cereus TD5B in the leather industry. In this study, sheep leather's physical properties were observed by measuring the tensile strength, elongation, and shrinkage temperature. Different alkaline protease concentration levels in this study showed significant differences $(P<0.05)$ in the tensile 
strength (Figure 6). The highest tensile strength was found on $1 \%$ alkaline protease dehairing, which was at $34.35 \pm 0.33 \mathrm{~N} / \mathrm{mm}^{2}$. The tensile strength measurement also showed that enzymatic dehairing of sheep leather by using $B$. cereus TD5B yields better tensile strength than the conventional dehairing, except at a $1.5 \%$ concentration level.

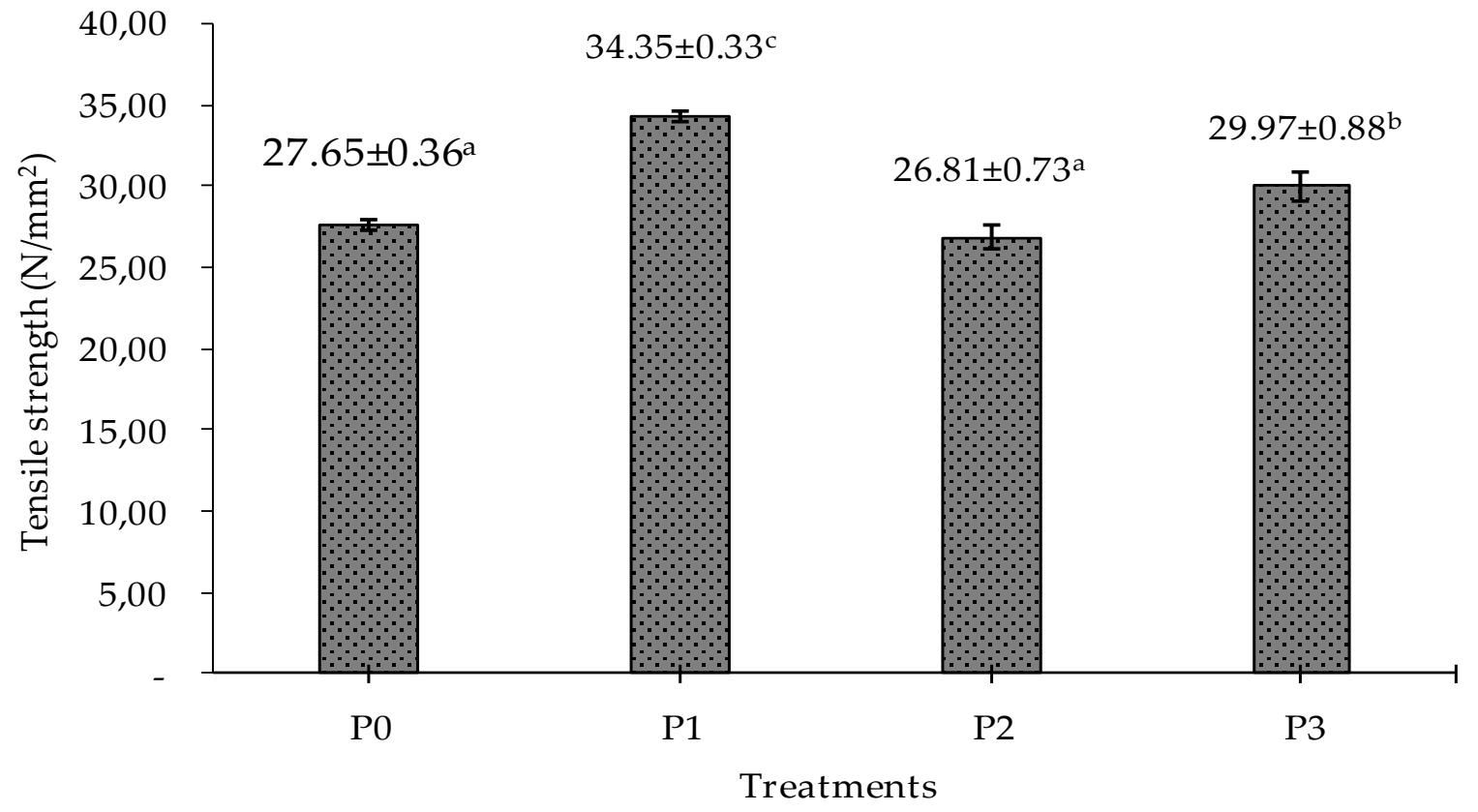

Figure 6. Tensile strength of sheep leather dehaired with different agents. $\mathrm{P} 0=0.5 \%$ lime and $3 \%$ $\mathrm{Na}_{2} \mathrm{~S} ; \mathrm{P} 1=1 \%$ alkaline protease; $\mathrm{P} 2=1.5 \%$ alkaline protease; $\mathrm{P} 3=2 \%$ alkaline protease. Different superscripts indicate significant difference $(P<0.05)$.

The elongation at break measurement of sheep leather in this study showed a significant difference between each treatment $(P<0.05)$, with the enzymatic dehairing of sheep skin, showed higher elongation compared to conventional dehairing except at 1.5\% alkaline protease concentration (Figure 7). Research has shown that enzymatic dehairing using alkaline protease from Bacillus strain produced leather with better tensile strength and elongation, which was $28 \pm 6$
$\mathrm{N} / \mathrm{mm}^{2} 39 \pm 1.3 \%$, respectively, on goat leather [9]. Other research [33] showed that goat dehairing by alkaline protease yields leather with elongation at $49.01 \pm 2.61 \%$ and tensile strength at $25.78 \pm 1.02 \mathrm{~N} / \mathrm{mm}^{2}$, both being higher compared to the conventional dehairing by using lime and sulfide. In addition, other research on goat skin dehairing by using bacterial alkaline protease also showed similar results [34]. 


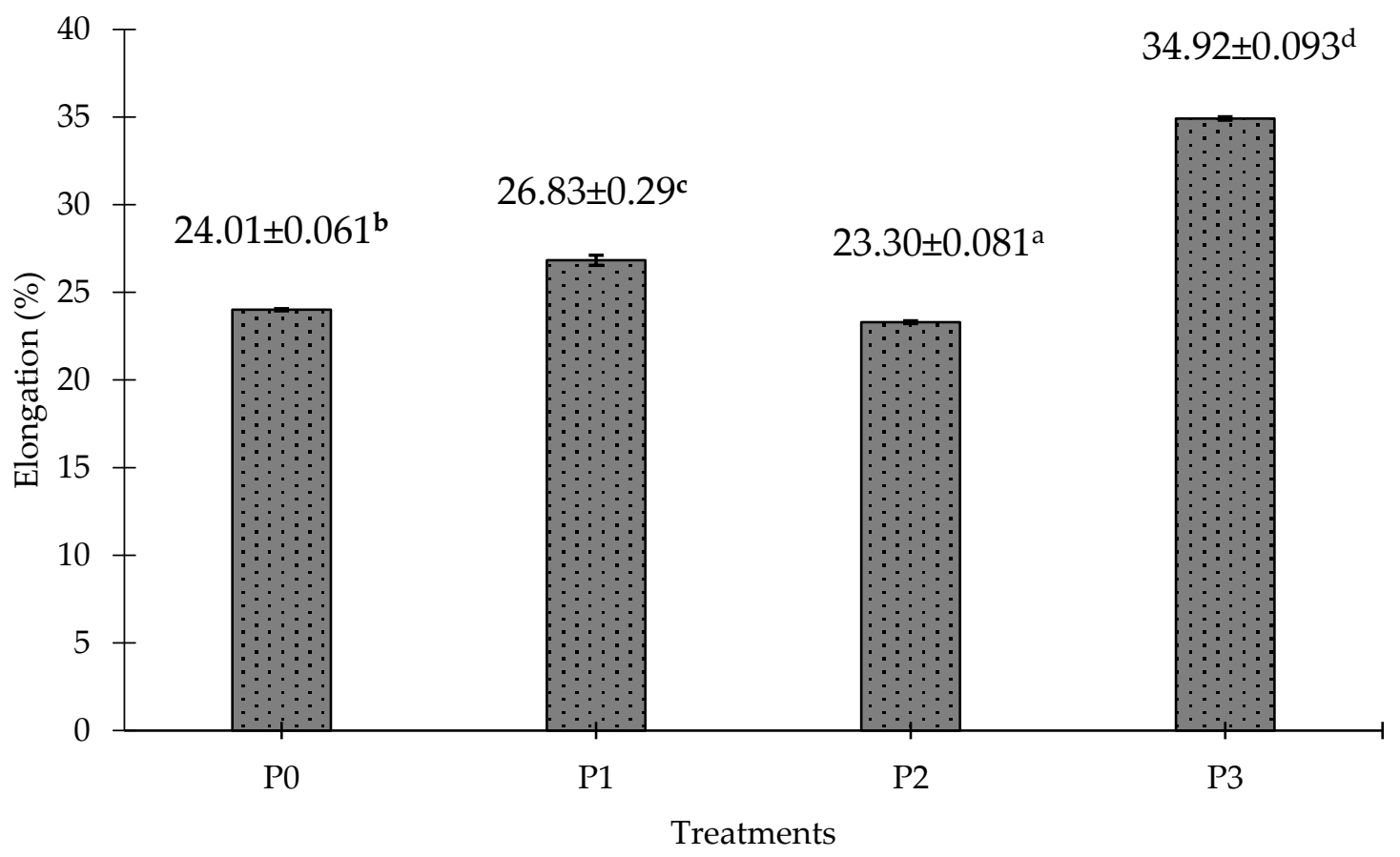

Figure 7. Elongation of sheep leather dehaired with agents. $\mathrm{PO}=0.5 \%$ lime and $3 \% \mathrm{Na}_{2} \mathrm{~S} ; \mathrm{P} 1=1 \%$ alkaline protease; $\mathrm{P} 2=1.5 \%$ alkaline protease; $\mathrm{P} 3=2 \%$ alkaline protease. Different superscripts indicate significant difference $(\mathrm{P}<0.05)$.

This study's shrinkage temperature measurement showed similar results between leather with conventional dehairing and enzymatic dehairing at different alkaline protease concentration levels. In the process of leather tanning, the fibers were strengthened by chemical cross-linking bonds formation among molecular collagen chains [35]. Tanned leather's shrinkage temperature is an important index for hydrothermal stability, especially for leather intended for outwear manufacturing subjected to hot temperature. Research showed that the shrinkage temperature of sheep skin tanned using syntan containing active chlorine group was $81.6^{\circ} \mathrm{C}$, lower than found in this study [36]. Another research found that the use of epoxy resin as a sole tanning agent showed leather shrinkage temperature at $85^{\circ} \mathrm{C}$ [37]. In this study, the tanning of sheep skin was done using chrome, and the obtained shrinkage temperature was found at $90^{\circ} \mathrm{C}$. This showed the enzymatic dehairing of sheep skin by using alkaline protease from $B$. cereus TD5B yield matching the shrinkage temperature to that of conventionally dehaired leather.

\section{CONCLUSIONS}

The extracellular alkaline protease enzyme from Bacillus cereus TD5B was detected and showed the potential to be used as an alternative for lime-sulfide dehairing for sheep skin. The optimum alkaline protease concentration of $B$. cereus TD5B was found at the highest concentration of the study, which was at $2 \%$, thus indicating better dehairing at a higher concentration.

\section{Acknowledgements}

This work was supported by "Hibah Penelitian Tematik 2015", Laboratory of Leather, Animal Waste, By-Products Technology, Faculty of Animal Science, Universitas Gadjah Mada. 


\section{REFERENCES}

1. Covington, A.D., Tanning Chemistry: The Science of Leather; Royal Society of Chemistry, United Kingdom, 2009, 464.

2. Ferreira, M.J., Almeida, M.F., Pinho, S.C., Santos, I.C., Finished leather waste chromium acid extraction and anaerobic biodegradation of the products, Waste Manag, 2010, 30, 6, 1091-1100, https://doi.org/10.1016/j.wasman.2009.12.006.

3. Ramasami, T., Rao, R.J., Chandrababu, N.K., Parthasarathy, K., Rao, P.G., Saravanan, P., Gayatri, R., Sreeram, K.J., Beamhouse and tanning operations: A revisit to process chemistry, J Soc Leather Technol Chem, 1999, 83, 39-45.

4. Thanikaivelan, P., Rao, R.J., Nair, B.U., Ramasami, T., Progress and recent trends in biotechnological methods for leather processing, Trends Biotechnol, 2004, 22, 4, 181-188, https://doi.org/10.1016/j.tibtech.2004.02.00.

5. Kumar, V.E., Srijana, M., Kumar, K., Harikrishna, N., Reddy, G., A novel serine alkaline protease from Bacillus altitudinis GVC11 and its application as a dehairing agent, Bioproc Biosyst Eng, 2011, 34, 403409, https://doi.org/10.1007/s00449-0100483-x.

6. Genckal, H., Tari, C., Alkaline protease production from alkalophilic Bacillus sp. isolated from natural habitats, Enzyme Microb Tech, 2006, 39, 4, 703-710, https://doi.org/10.1016/j.enzmictec.2005. 12.004

7. Gupta, R.I., Patel, R.K., Singh, S.P., Khare, S.K., Gupta, M.N., One step purification and characterization of an alkaline protease from haloalkaliphilic Bacillus sp, $J$ Chromatogr A, 2005, 1075, 1-2, 103-108, https://doi.org/10.1016/j.chroma.2005.03.127.

8. Sun, F., Hu, Y., Chen, Q., Kong, B., Qian, L., Purification and biochemical characteristics of the extracellular protease from Pediococcus pentosaceus isolated from Harbin dry sausages, Meat Sci, 2019, 156, 156-165, https://doi.org/10.1016/j.meatsci.2019.05.030.

9. Briki, S., Hamdi, O., Landoulsi, A., Enzymatic dehairing of goat skins using alkaline protease from Bacillus sp. SB12, Prot Express Pur, 2016, 121, 9-16, https://doi.org/10.1016/j.pep.2015.12.02.

10.Fitriyanto, N.A., Oktaria, V., Erwanto, Y., Rusman., Hayakawa, T., Nakagawa, T., Kawai, K., Isolation and Characterization of Protease Producing Strain Bacillus cereus from Odorous Farm Soil in Tropical Area. In Sustainable Livestock Production in the Perspective of Food Security, Policy, Genetic Resources and Climate Change, Proceedings of the 16th AAAP Animal Science Congress, Yogyakarta, Indonesia, 2014, J 522 ID, 1308-1311.

11.Winarti, A., Fitriyanto, N.A., Jamhari, Pertiwiningrum, A., Bachruddin, Z., Pranoto, Y., Erwanto, Y., Optimizing of protease purification from Bacillus cereus TD5B by ammonium sulfate precipitation, Chem Eng Trans, 2018, 63, 709-714, https://doi.org/10.3303/CET1863119.

12.Winarti, A., Rahmawati, F., Fitriyanto, N.A., Jamhari, J., Erwanto, Y., Hydrolyzation of duck meat protein using Bacillus cereus TD5B protease, pepsin, trypsin and their potency as an angiotensin converting enzyme 
inhibitor, JITAA 2016, 44, 3, 266-276, https://doi.org/10.14710/jitaa.44.3.266-276.

13.Wandita, T.G., Triatmojo, S., Gumilar, J., Fitriyanto, N.F., Production and application of keratinase enzyme from 4 strains of Bacillus spp. isolated from Yogyakarta and Garut city, Indonesia, Asian J Microbiol Biotechnol Envir Sci, 2016, 18, 2, 71-78.

14.Fitriyanto, N.A., Winarti, A., Imara, F.A., Erwanto, Y., Hayakawa, T., Nakagawa, T., Identification and growth characters of nitrifying Pseudomonas sp. LS3K isolated from odorous region of poultry farm, J Biol Sci, 2017, 17, 1-10, https://doi.org/10.3923/jbs.2017.1.10.

15.Mitra, P., Chakrabartty, P.K., An extracellular protease with depilation activity from Streptomyces nogalator, J Sci Ind Res, 2005, 64, 978-983.

16.Kumar, C.G., Tiwari, M.P., Jany, K.D., Novel alkaline serine protease from alkalophilic Bacillus sp. purification and characterization, Process Biochem, 1999, 34, 5, 441-449, https://doi.org/10.1016/S00329592(98)00110-1.

17.Bancroft, J.D., Gamble, M., Theory and practice of histological techniques, in Jones, M.L., Totty, B.A. (Eds.), Connective Tissues and Stains, 5th ed., Churchill Livingstone Publications: London, United Kingdom, 2004, 139-200.

18. International Organization for Standardization, ISO 3376: 2011 (IULTCS/IUP 6) Leather - Physical and Mechanical Test - Determination of Tensile Strength and Percentage extension,
Geneva Switzerland, 2011, https://www.iso.org/standard/51510.html.

19.International Organization for Standardization, ISO 17236:2016

(IULTCS/IUP 43) Leather - Physical and mechanical tests - Determination of extension set, Geneva Switzerland, 2016, https://www.iso.org/standard/68863.html.

20.International Organization for Standardization, ISO 3380:2015 (IULTCS/IUP 16) Leather - Physical and mechanical tests - Determination of shrinkage temperature up to $100^{\circ} \mathrm{C}$, Geneva Switzerland, 2015, https://www.iso.org/standard/61792.html.

21.Saitou, N., Nei, M., The neighbor-joining method: a new method for reconstructing phylogenetic trees, Mol Biol Evol, 1987, 24, 4, 189-204, https://doi.org/10.1093/oxfordjournals.mo Ibev.a040454.

22.Anwar, A., Saleemuddin, M., Alkaline proteases: A review, Biores Technol, 1998, 64, 3, 175-183, https://doi.org/10.1016/S09608524(97)00182-X.

23.Macedo, A.J., Beys da Silva, W.O., Gava, R., Driemeier, D., Pêgas Henriques, J.A., Termignoni, C., Novel keratinase from Bacillus subtilis S14 exhibiting remarkable dehairing capabilities, Appl Environ Microbiol, 2005, 71, 594-596, https://doi.org/10.1128/AEM.71.1.594596.2005.

24.Kasana, R.C., Yadav, S.K., Isolation of a psychrotrophic Exiguobacterium sp. SKPB5 (MTCC7803) and characterization of its alkaline protease, Curr Microbiol, 2007, 54, 
224-229, https://doi.org/10.1007/s00284006-0402-1.

25. Vijayaraghavan, P., Lazarus, S., Vincent, S.G.P., De-hairing protease production by an isolated Bacillus cereus strain AT under solid-state fermentation using cow dung: Biosynthesis and properties, Saudi J Biol Sci, 2014, 21, 1, 27-34, https://doi.org/10.1016/j.sjbs.2013.04.010. 26.Al-Dhabi, N.A., Esmail, G.A., Ghilan, A.K.M., Arasu, M.V., Duraipandiyan, D., Ponmurugan, K., Characterization and fermentation optimization of novel thermo stable alkaline protease from Streptomyces sp. Al-Dhabi-82 from the Saudi Arabian environment for eco-friendly and industrial applications, J King Saud Univ - Sci, 2020, 32, 1, 1258-1264, https://doi.org/10.1016/j.jksus.2019.11.01.

27.Abusham, R.A., Rahman, R.N.Z.R., Salleh, A.B., Basri, M., Optimization of physical factors affecting the production of thermostable organic solvent-tolerant protease from a newly isolated halo tolerant Bacillus subtilis strain Rand, Microb Cell Fact, 2009, 8, 1-9, https://doi.org/10.1186/14752859-8-20.

28. Toyokawa, Y., Takahara, H., Reungsang, A., Fukuta, M., Hachimine, Y., Tachibana, S., Yasuda, M., Purification and characterization of a halotolerant serine proteinase from thermotolerant Bacillus licheniformis RKK-04 isolated from Thai fish sauce, Appl Microbiol Biotechnol, 2010, 86, 1867-1875, https://doi.org/10.1007/s00253-009-2434-5.

29.Shinde, A.A., Shaikh, F.K., Padul, M.V., Kachole, M.S., Bacillus subtilis RTSBA6.00, a new strain isolated from gut of Helicoverpa armigera (Lepidoptera: Noctuidae) produces chymotrypsin-like proteases, Saudi J Biol Sci, 2012, 19, 3, 317-323, https://doi.org/10.1016/j.sjbs.2012.03.001.

30.Vijayaraghavan, P., Vincent, S.G.P., Cow dung as a novel, inexpensive substrate for the production of a halo-tolerant alkaline protease by Halomonas sp. PV1 for ecofriendly applications, Biochem Eng J, 2012, $69,57-60$ https://doi.org/10.1016/j.bej.2012.08.014.

31.Galarza, B.C., Cavello, I., Greco, C.A., Hours, R., Schuldt, M.M., Cantera, C.S., Alternative Technologies for adding value to bovine hair waste, J Soc Leather Technol Chem, 2009, 94, 26-32.

32.Dettmer, A., Ayub, M.A.Z., Gutterres, M., Hide unhairing and characterization of commercial enzymes used in leather manufacture, Braz J Chem Eng, 2011, 28, 3, 373-380, https://doi.org/10.1590/S010466322011000300003.

33. George, N., Chauhan, P.S., Kumar, V., Puri, N., Gupta, N., Approach to ecofriendly leather: characterization and application of an alkaline protease for chemical free dehairing of skins and hides at pilot scale, $J$ Clean Prod, 2014, 79, 249-257, https://doi.org/10.1016/j.jclepro.2014.05.04.

34.Sivasubramanian, S., Manohar, B.M., Rajaram, A., Puvanakrishnan, R., Ecofriendly lime and sulfide free enzymatic dehairing of skins and hides using a bacterial alkaline protease, Chemosphere, 2008, 70, 6, 1015-1024, https://doi.org/10.1016/j.chemosphere.20 07.09.036. 
35.Koloka, O., Moreki, J.C., Tanning hides and skins using vegetable tanning agents in Hukuntsi sub-district, Botswana J Agr Tech, 2011, 7, 4, 915-922, available online http://www.ijat-aatsea.com.

36.Yu, L., Qiang, X., Cui, L., Chen, B., Wang, X., Wu, X., Preparation of a syntan containing active chlorine groups for chrome-free tanned leather, J Clean Prod, 2020, 270, 122351 , https://doi.org/10.1016/j.jclepro.2020.122 351.
37.Di, Y., Heath, R.J., Collagen stabilization and modification using a polyepoxide, triglycidyl isocyanurate, Polym Degrad Stabil, 2009, 94, 10, 1684-1692, https://doi.org/10.1016/j.polymdegradsta b.2009.06.019.

(C) 2021 by the author(s). Published by INCDTPICPI, Bucharest, RO. This is an open access article distributed under the terms and conditions of the Creative Commons Attribution license (http://creativecommons.org/licenses/by/4.0/). 